\title{
The genetics of signal transduction and the outcome of diagnostic tests in growth retardation
}

\author{
E Bottini, N Lucarini ${ }^{1}$, A Amante, N Bottini ${ }^{2}$ and G Faggioni \\ Department of Biopathology and Image Diagnostics, Division of Preventive and Social Pediatrics, University of Rome, Tor Vergata, School of Medicine, \\ Rome, Italy \\ ${ }^{1}$ Department of MCA Biology, University of Camerino, School of Science, Camerino, Italy \\ ${ }^{2}$ The Burnham Institute, La Jolla, California, USA \\ (Requests for offprints should be addressed to E Bottini, Università degli Studi di Roma, Tor Vergata, Dipartimento di Biopatologia e Diagnostica per Immagini, \\ Via della ricerca scientifica 1, 00133 Roma, Italy; Email: bottini@med.uniroma2.it)
}

\begin{abstract}
The effects of 'normal' genetic variability of signal transduction on endocrine function may be more evident during stimulation tests than is observed in basal states, thereby contributing to a greater understanding of the possible role of signal transduction genetics in the pathogenesis of endocrine disorders. In the present study, we have studied the outcome of growth hormone $(\mathrm{GH})$ stimulation testing by insulin in growth-retarded children in relation to the genotype of ACP1 (acid phosphatase locus 1; also referred to as cLMWPTP, cytosolic low molecular weight phosphotyrosine phosphatase). ACP1 is an enzyme, expressed as two distinct isoforms designated $\mathrm{F}$ and $\mathrm{S}$, that down-regulates insulin receptor signal transduction and which shows a genetic polymorphism with
\end{abstract}

strong quantitative enzymatic differences among genotypes. In this study, we examined 116 growth-retarded children of which 101 were genotyped for ACP1. We found that the basal level of $\mathrm{GH}$ is higher in ACP1 genotypes with low concentrations of the $\mathrm{S}$ isoform than in genotypes with high $\mathrm{S}$ isoform concentrations $(P<0 \cdot 02)$. Additionally, during GH stimulation with insulin, the genotypes with low $\mathrm{S}$ isoform concentrations were found to perform better $(P<0 \cdot 005)$ and to react more promptly than the genotypes with high $\mathrm{S}$ isoform concentrations $(P<0 \cdot 05)$. These findings suggest that high $\mathrm{S}$ isoform ACP1 activity slows down the effect of insulin, resulting in a retardation of its metabolic effect.

Journal of Endocrinology (2001) 171, 267-271

\section{Introduction}

Based on the outcome of growth hormone (GH) stimulation tests, growth retardation in children is commonly classified into three categories: familial short stature, partial deficit and total deficit of GH. It is likely that such classification, although useful in clinical practice, does not correctly reflect the multifactorial origin of the great majority of these disorders. A multivariate continuous distribution of relevant auxologic and endocrine parameters may be more realistic, while incorrect representation may, in part, account for the poor reproducibility of clinical categorical definitions (Rose et al. 1988, Cacciari et al. 1992).

It is likely that many factors are involved in the determination of relevant clinical parameters of growth retardation. Some of these factors may be intrinsic to $\mathrm{GH}$ genetic differences, while others may be involved in receptor and signal transduction mechanisms. However, the effects of 'normal' genetic variability of signal transduction on basal endocrine function may not discern important differences that are detectable following stimulation tests, a fact which led to the present study.

Acid phosphatase locus 1 (ACP1) is an enzyme involved in the signal transduction of insulin and other growth factors (Dissing 1993, Bottini et al. 1995, Chiarugi et al. 1997, Ramponi \& Stefani 1997). ACP1 is encoded at a locus on chromosome 2 showing three common alleles *A, *B and *C (Dissing 1993, Bottini et al. 1995). The enzyme is expressed in mammals as two distinct isoforms, designated $\mathrm{F}$ and $\mathrm{S}$ with reference to their electrophoretic mobility. There are quantitative differences in total enzymatic activity and F/S ratio among ACP1 genotypes (see Bottini et al. 1995 for a review). In vitro experiments have shown that ACP1 down-regulates insulin receptor signal transduction (Chiarugi et al. 1997), and the ACP1 polymorphism has been found to be associated with glycemic levels in all forms of diabetes (Gloria-Bottini et al. 1996, Lucarini et al. 1998). These observations prompted us to examine the possible effect of ACP1 enzymatic variability on the results of GH stimulation by insulin in growthretarded children. 
Table 1 Clinically relevant variables in study sample

\begin{tabular}{|c|c|c|c|c|c|}
\hline & $\begin{array}{l}\text { Age } \\
\text { (years) }\end{array}$ & $\begin{array}{l}\text { Deviation from } \\
\text { mean stature } \\
\text { (in S.D.) }\end{array}$ & $\begin{array}{l}\text { Maternal } \\
\text { stature } \\
(\mathrm{cm})\end{array}$ & $\begin{array}{l}\text { Paternal } \\
\text { stature } \\
(\mathrm{cm})\end{array}$ & $\begin{array}{l}\text { Sex ratio } \\
(M / F)\end{array}$ \\
\hline \multicolumn{6}{|l|}{ FSS } \\
\hline Mean & $11 \cdot 3$ & $-2 \cdot 11$ & $152 \cdot 9$ & $164 \cdot 3$ & \multirow[t]{2}{*}{$2 \cdot 00$} \\
\hline S.D. & $2 \cdot 6$ & $0 \cdot 73$ & $4 \cdot 4$ & $4 \cdot 7$ & \\
\hline$n$ & 30 & 27 & 28 & 27 & 30 \\
\hline \multicolumn{6}{|l|}{ PD } \\
\hline Mean & $10 \cdot 3$ & $-2 \cdot 08$ & $154 \cdot 3$ & $168 \cdot 6$ & \multirow[t]{2}{*}{$2 \cdot 41$} \\
\hline S.D. & $3 \cdot 3$ & 0.96 & $5 \cdot 9$ & $6 \cdot 4$ & \\
\hline$n$ & 57 & 48 & 55 & 54 & 58 \\
\hline \multicolumn{6}{|l|}{$\mathrm{TD}$} \\
\hline Mean & $9 \cdot 9$ & $-2 \cdot 00$ & $154 \cdot 5$ & $168 \cdot 5$ & \multirow[t]{2}{*}{$1 \cdot 55$} \\
\hline S.D. & $4 \cdot 7$ & $0 \cdot 86$ & $7 \cdot 1$ & 6.9 & \\
\hline$n$ & 28 & 23 & 27 & 26 & 28 \\
\hline
\end{tabular}

\section{Subjects and Methods}

One hundred and sixteen growth-retarded children in the population of Ancona, Italy have been studied; the ACP1 genotype was determined in 101 of these children. Insulin and clonidine stimulation tests were performed in all subjects. The GH value (plasma level in $\mu \mathrm{g} / \mathrm{l}$ ) at the end of the test was considered for classification into three categories: total deficit (TD), partial deficit (PD) and familial short stature (FSS). For insulin stimulation the cut-off points were 4 (PD vs TD) and 8 (FSS vs PD) $\mu \mathrm{g} / 1$ for the level of $\mathrm{GH}$ at $60 \mathrm{~min}$ from the beginning of the test and for clonidine testing 6 and $10 \mu \mathrm{g} / \mathrm{l}$ respectively at $30 \mathrm{~min}$ from the beginning of the test were used. Both test results had to be below the cut-off point in order to include the patient in the lower class. Based on the results of $\mathrm{GH}$ stimulation tests with insulin and clonidine, among children in whom ACP1 genotype was determined 23 were classified as FSS, 54 as PD and 24 as TD of GH. With the exception of two subjects (one TD and one PD) who showed an associated deficit of thyrotropin (TSH), all cases had isolated GH deficiency. No other evident cause of growth retardation such as malabsorption was present, and no sign of sellar area lesion was detectable.

ACP1 genotyping was determined according to the classical method of Hopkinson et al. (1963). Indeed, only recently was a method developed which allows the determination of all ACP1 types by DNA analyses (Lazaruk 1995). In our laboratory, we have recently determined ACP1 types by the two methods (classical and by DNA analysis) in a sample of diabetic subjects and their parents. The results by the two methods were very similar. For our analyses in the present study, subjects were subdivided into two categories: low-medium ACP1 activity $\left(* \mathrm{~A} /{ }^{*} \mathrm{~A}\right.$, ${ }^{*} \mathrm{~A} /{ }^{*} \mathrm{~B}$ and $\left.{ }^{*} \mathrm{~B} /{ }^{*} \mathrm{~B}\right)$ and high activity $\left({ }^{*} \mathrm{~A} /{ }^{*} \mathrm{C},{ }^{*} \mathrm{~B} /{ }^{*} \mathrm{C}\right.$ and $\left.{ }^{*} \mathrm{C} /{ }^{*} \mathrm{C}\right)$. The first class includes genotypes with very low
$\mathrm{S}$ isoform concentrations $(<4 \mu \mathrm{g} / \mathrm{ml}$ red blood cells) and the second class those with high $\mathrm{S}$ isoform concentrations (>12 $\mu \mathrm{g} / \mathrm{ml}$ red blood cells) (Bottini et al. 1995).

Statistical analyses were performed by SPSS programs (SPSS/PC+ version 5.0 1995; SPSS Inc., Chicago, IL, USA). Probabilities in Table 2 were combined according to the method described by Sokal and Rohlf (1981). Informed consent was obtained by the parents of children prior to testing. The investigation was performed during the years 1985-1995 in collaboration between the Laboratory of Genetics of the University of Camerino and the Institute of Pediatric Clinic of the University of Ancona. It is noteworthy that, at present, insulin challenge testing is no longer used in Italian Pediatric Clinics.

\section{Results}

Clinically relevant parameters of the study sample are shown in Table 1. Table 2 shows the basal level of plasma $\mathrm{GH}$ in genotypes with high and low ACP1 S isoform concentrations. We found that the level of $\mathrm{GH}$ is higher in children with low $\mathrm{S}$ isoform concentrations than in those with high $\mathrm{S}$ isoform concentrations $(P<0 \cdot 02)$. No statistically significant difference in the deviation from normal stature has been observed between children with high and low $\mathrm{S}$ isoform concentrations.

Figure 1 shows the results of $\mathrm{GH}$ stimulation by insulin in ACP1 genotypes with low $\mathrm{S}$ isoform concentrations and in those with high $\mathrm{S}$ isoform concentrations separately for FSS and PD subjects. TD was not considered for this analysis since the increase of $\mathrm{GH}$ during the stimulation test was minimal. These data show that low $\mathrm{S}$ genotypes performed better than high $\mathrm{S}$ genotypes in both FSS and PD (cumulative $P<0 \cdot 005$ ). The results obtained by stimulation by clonidine are similar to those obtained by insulin 
Table 2 Basal level of plasma GH $(\mu \mathrm{g} / \mathrm{l})$ in genotypes with low and in those with high $\mathrm{ACP} 1 \mathrm{~S}$ isoform concentrations

\begin{tabular}{|c|c|c|c|}
\hline & $\begin{array}{l}{ }^{*} \mathrm{~A} /{ }^{*} \mathrm{~A},{ }^{*} \mathrm{~A} /{ }^{*} \mathrm{~B} \text { and }{ }^{*} \mathrm{~B} /{ }^{*} \mathrm{~B} \\
\text { genotypes (low } \mathrm{S} \text { ) }\end{array}$ & $\begin{array}{l}{ }^{*} \mathrm{~A} /{ }^{*} \mathrm{C},{ }^{*} \mathrm{~B} /{ }^{*} \mathrm{C} \text { and }{ }^{*} \mathrm{C} /{ }^{*} \mathrm{C} \\
\text { genotypes (high } \mathrm{S} \text { ) }\end{array}$ & $\begin{array}{l}\text { Significance } \\
\text { of difference } \\
(P)\end{array}$ \\
\hline \multicolumn{4}{|l|}{ FSS } \\
\hline Mean & $4 \cdot 6$ & $2 \cdot 1$ & \multirow[t]{3}{*}{$0 \cdot 015$} \\
\hline S.E. & $0 \cdot 9$ & $0 \cdot 0$ & \\
\hline$n$ & 22 & 1 & \\
\hline \multicolumn{4}{|l|}{ PD } \\
\hline Mean & $3 \cdot 4$ & $3 \cdot 1$ & \multirow[t]{3}{*}{$0 \cdot 700$} \\
\hline S.E. & $0 \cdot 4$ & $0 \cdot 9$ & \\
\hline$n$ & 46 & 8 & \\
\hline \multicolumn{4}{|l|}{ TD } \\
\hline Mean & $3 \cdot 9$ & $2 \cdot 1$ & \multirow[t]{3}{*}{$0 \cdot 045$} \\
\hline S.E. & $0 \cdot 8$ & $0 \cdot 1$ & \\
\hline$n$ & 25 & 2 & \\
\hline \multicolumn{3}{|c|}{ Combined probabilities* } & $<0 \cdot 02$ \\
\hline
\end{tabular}

*Probabilities were combined according to the method of Sokal \& Rohlf (1981).

but the differences between low and high $\mathrm{S}$ genotypes are much less marked and statistically not significant (data not shown).

In both FSS and PD subjects the rise of plasma GH in the initial period of stimulation by insulin is slower in subjects with high $\mathrm{S}$ than in those with low $\mathrm{S}$ activity. In subjects with low $\mathrm{S}$ activity, the maximum plasma $\mathrm{GH}$ level is reached within 30-45 min, while in subjects with high $S$ activity the maximum is reached after 45-60 min, at a time when the plasma GH level is already decreasing in subjects with low $\mathrm{S}$ activity. Table 3 shows a cumulative analysis of data in FSS and PD subjects. The difference in GH plasma level between low and high $\mathrm{S}$ activity genotypes is statistically significant only during the first $30 \mathrm{~min}$.

A correlation analysis between the concentration of $\mathrm{S}$ (and F) isoform of ACP1 and the rise of plasma GH at $30 \mathrm{~min}$ from insulin infusion has shown that the $\mathrm{S}$ isoform

Table 3 The rise of plasma GH after stimulation with insulin in subjects with low $\mathrm{S}$ concentration and in subjects with high $\mathrm{S}$ concentration. Cumulative analysis on FSS and PD subjects. The zero hypothesis is that there is no difference between low and high $\mathrm{S}$ concentration ACP1 genotypes

\begin{tabular}{|c|c|}
\hline \multicolumn{2}{|c|}{$\begin{array}{l}\text { Difference between low and } \\
\text { high } S \text { concentration ACP1 } \\
\text { genotypes }\end{array}$} \\
\hline$<30$ min Pll & $>30$ min PII \\
\hline $3 \cdot 60$ & $2 \cdot 70$ \\
\hline $1 \cdot 32$ & $1 \cdot 58$ \\
\hline 77 & 77 \\
\hline$<0.05$ & N.S. \\
\hline
\end{tabular}

N.S., not significant. PII, post insulin infusion. is negatively correlated with the rise of $\mathrm{GH}$, while the $\mathrm{F}$ isoform does not exert any apparent influence on this rise (data not shown).

In the sample of PD cases we generated a polynomial approximation of the functional relationship between $\mathrm{GH}$ level and time in low $\mathrm{S}$ activity subjects. The function best fitting the rise of $\mathrm{GH}$ is a four order polynomial: $\mathrm{Y}=0 \cdot 371$ $x^{4}-3 \cdot 04 x^{3}+7 \cdot 03 x^{2}-2 \cdot 56 x$ (where $Y$ is GH plasma level and $\mathrm{x}=$ time in $\mathrm{min}$ ). After transformation of the data, the relationship between plasma GH level and time becomes linear in low $\mathrm{S}$ activity but not in high activity subjects (data not shown). This confirms the differences between low $\mathrm{S}$ and high $\mathrm{S}$ genotypes with respect to their impact on the relationship between time and rise of plasma $\mathrm{GH}$ during stimulation.

It is also noteworthy that the pattern of $\mathrm{GH}$ response to stimulation with insulin and clonidine was not found to have significant differences between sexes or between age classes.

\section{Discussion}

Experimental evidence indicates that $\mathrm{F}$ and $\mathrm{S}$ isozymes elicit structural differences in their catalytic sites and have different cellular target substrates. It is likely, therefore, that they perform different physiological functions. Indeed, Stefani et al. (1993) have shown that $S$ and $\mathrm{F}$ isoforms have somewhat different interactions with the insulin receptor. This may explain the differences observed in our study between high and low S ACP1 genotypes.

The role of many protein tyrosine phosphatases (PTPases) in modulating insulin receptor signal transduction has 


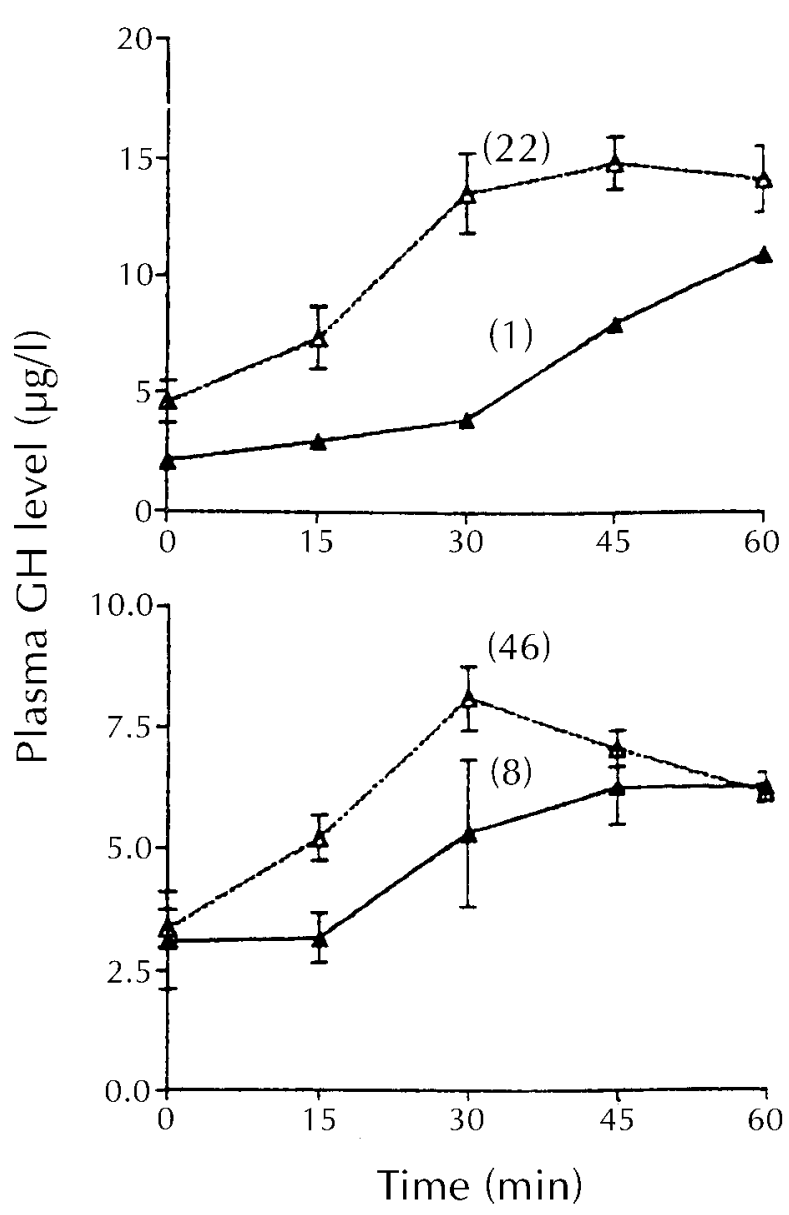

Figure 1 Rise of plasma GH concentrations after stimulation with insulin in FSS subjects (upper panel) and in PD subjects (lower panel) with low activity $\left({ }^{*} \mathrm{~A} /{ }^{*} \mathrm{~A},{ }^{*} \mathrm{~A} /{ }^{*} \mathrm{~B}\right.$ and $\left.{ }^{*} \mathrm{~B} /{ }^{*} \mathrm{~B} ; \triangle\right)$ and with high activity $\left({ }^{*} \mathrm{~A} /{ }^{*} \mathrm{C},{ }^{*} \mathrm{~B} /{ }^{*} \mathrm{C}\right.$ and ${ }^{*} \mathrm{C} /{ }^{*} \mathrm{C}$; $\left.\Delta\right)$ ACP1 genotypes. The number of subjects is shown in parentheses. The cumulative test of significance for the difference between genotypes with low and high $\mathrm{S}$ isoform concentrations is $P<0 \cdot 005$.

been demonstrated by in vitro experiments (Goldstein et al. 1998), and recently the in vivo role of PTPases in the modulation of insulin action has been investigated by the generation of a knock-out mouse model for one of these enzymes (Elchebly et al. 1999). Among the PTPases involved in insulin receptor signal transduction, ACP1 is the only one associated with 'normal' variability of enzymatic activity due to a known genetic polymorphism. The present data seems to confirm the in vivo involvement of ACP1 in insulin signal transduction, suggesting that ACP1 genetic variability influences the outcome of stimulation testing: high PTPase activity appears to slow down the effects of insulin, resulting in retardation of its metabolic effects. In turn, the fact that basal levels of plasma GH in all classes of patients were found to be higher in low $S$ than in high S ACP1 genotypes also suggests that in physio- logical conditions ACP1 activity may correlate negatively with GH plasma levels.

The differences observed between insulin and clonidine effects suggest that the pathway of clonidine action may not be as strictly dependent on the phosphorylation cascade as that of insulin action. That is, the effects of ACP1 activity are much stronger with insulin than with clonidine pathway activation.

In our subjects no direct measurements of glucose response level to infusion of insulin have been performed. Therefore, although the infusion may represent an insulin tolerance test, since the GH response is further removed from the insulin effects, at present it cannot be excluded that some effect of ACP1 is acting at an intermediate step of the pathway, including a possibly direct effect on pituitary function. In a more general context, our observations may have clinical relevance in those situations in which the measurable effect of a stimulation test is modulated by receptor and/or tranduction systems showing quantitative genetic variability.

\section{Acknowledgements}

This study was possible thanks to the long term friendly cooperation of Prof. P L Giorgi, formerly Director of the Pediatric Clinic of the University of Ancona, and of his collaborators. The investigation was supported by a CNR grant to $\mathrm{E} \mathrm{B}$.

\section{References}

Bottini E, Gloria-Bottini F \& Borgiani P 1995 ACP1 and human adaptability. 1. Association with common diseases: a case-control study. Human Genetics 96 629-637.

Cacciari E, Tassoni P, Parisi G, Pirazzoli P, Zucchini S, Mandini M, Cicognani A \& Balsamo A 1992 Pitfalls in diagnosing impaired growth hormone $(\mathrm{GH})$ secretion: retesting after replacement therapy of 63 patients defined as GH deficient. Journal of Clinical Endocrinology and Metabolism 74 1284-1289.

Chiarugi P, Cirri P, Marra F, Raugei G, Camici G, Manao G \& Ramponi G 1997 LMW-PTP is a negative regulator of insulin-mediated mitotic and metabolic signaling. Biochemical and Biophysical Research Communications 238 676-682.

Dissing J 1993 Human 'red cell' acid phosphatase (ACP1) genetic, catalytic and molecular properties. $\mathrm{PhD}$ thesis. Kobenhavn Universitat, Kobenhavn, Denmark.

Elchebly M, Payette P, Michaliszyn E, Cromlish W, Collins S, Loy AL, Normandin D, Cheng A, Himms-Hagen J, Chan CC, Ramachandran C, Gresser MJ, Tremblay ML \& Kennedy BP 1999 Increased insulin sensitivity and obesity resistance in mice lacking the protein tyrosine phosphatase-1B gene. Science $\mathbf{2 8 3}$ 1544-1548.

Gloria-Bottini F, Gerlini G, Lucarini N, Borgiani P, Amante A, La Torre M, Antonacci E \& Bottini E 1996 Phosphotyrosine protein phosphatases and diabetic pregnancy: an association between low molecular weight acid phosphatase and degree of glycemic level. Experientia 52 340-343.

Goldstein BJ, Ahmad F, Ding W, Li PM \& Zhang WR 1998 Regulation of the insulin signalling pathway by cellular proteintyrosine phosphatases. Molecular and Cellular Biochemistry 182 91-99. 
Hopkinson DA, Spencer N \& Harris H 1963 Red cell acid phosphatase variants: a new human polymorphism. Nature 199 969-971.

Lazaruk KDA 1995 Molecular genetics of human red cell acid phosphatase. PhD dissertation. University of California, Berkeley, Prof. Sensabaugh G.F. Chair.

Lucarini N, Antonacci E, Bottini N, Borgiani P, Faggioni G \& Gloria-Bottini F 1998 Phosphotyrosine-protein-phosphatase and diabetic disorders. Further studies on the relationship between low molecular weight and phosphatase genotype and degree of glycemic control. Disease Markers 14 121-125.

Ramponi G \& Stefani M 1997 Structure and function of the low $M$ phosphotyrosine protein phosphatase. Biochimica et Biophysica Acta 134 137-157.
Rose SR, Ross JL, Uriarte M, Barnes KM, Cassorla FG \& Cutler GB Jr 1988 The advantage of measuring stimulated as compared with spontaneous growth hormone levels in the diagnosis of growth hormone deficiency. New England Journal of Medicine 319 201-207. Sokal R \& Rohlf JF 1981 Biometry. New York: WH Freeman.

Stefani M, Caselli A, Bucciantini M, Pazzagli L, Dolfi F, Camici G, Manao G \& Ramponi G 1993 Dephosphorylation of tyrosine phosphorylated synthetic peptides by rat liver phosphotyrosine protein phosphatase isoenzymes. FEBS Letters 326 131-134.

Received in final form 8 June 2001 Accepted 9 July 2001 